\title{
THE ROLE OF FOREIGN LANGUAGE AS A BRAND OF PRODUCT FROM CONSTRUCTIVISM POINT A VIEW
}

\author{
Abraham Christariana Prastono ${ }^{1}$; Eumyrio Ytsar ${ }^{2}$; Bhimasurya Gusti Putra ${ }^{3}$; Samudra Danega \\ Mustokohaji ${ }^{4}$; Moses Glorino Rumambo Pandin ${ }^{5}$ \\ abraham.christariana.prastono-2020@fib.unair.ac.id ${ }^{1}$; eumyrio.ytsar-2020@fib.unair.ac.id²; \\ bhimasurya.gusti.putra-2020@ fib.unair.ac.id ${ }^{3}$; samu.danega.mustokohaji- \\ $2020 @$ fib.unair.ac.id ${ }^{4}$; moses.glorino@ fib.unair.ac.id ${ }^{5}$ \\ Faculty of Humanities, Universitas Airlangga \\ Jl. Airlangga No. 4-6, Airlangga, Kec. Gubeng, Kota Surabaya, Jawa Timur 60115 \\ *Corresponding author: Abraham Christariana Prastono \\ abraham.christariana.prastono-2020@fib.unair.ac.id
}

\begin{abstract}
The identity of a product has an important part for the company. Product identity should have the unique aspect to draw attention of customers and to win the competition with the other competitors. Nowadays, the identity of a product with foreign language is having uptrends because most people think it is unique and draws more attention. Therefore, foreign language has an influence to the identity of a brand. The development of technology and language make most of the owner of a product choose a foreign language than Indonesian language. Moreover, the assumption of Indonesian language does not have a rich vocabulary than Indonesian language become the main reason. Besides that, an identity of a brand with foreign language can deliver the main point of a product to the customer. From the context of the problem raised, there are some question asked, how does a foreign language in the identity of a product can affect the buyer's decision process? And what is the solution to raise the use of Indonesian language for the identity of a product? This study used qualitative research with a questionnaires and interviews as a way to collecting data. Therefore, the author hopes this research can contribute to language development and local product in Indonesia. From the research with questionnaires and interviews, it showed that most people tend to choose a brand of a product with a foreign language. However, the Indonesian language product brands also have the big contribution to the increase of Indonesian economic.
\end{abstract}

Keywords: Identity, foreign, language, product, influence.

\section{INTRODUCTION}

Determining the identity of a product is crucial because the identity of the product greatly influences the public's decision to buy a product and is important in competition with 
other competitors. If a product's identity does not draw attention, it will almost certainly be unable to compete with numerous competitors out there. Companies are required to continuously improve products, maintain excellence, uniqueness, and attractiveness in competing as the level of competition in meeting consumer needs rises. Proper and appropriate marketing tricks are required to win the hearts of consumers. Companies must be able to learn how consumers decide which products to buy by offering appropriate promotions, price matching, and equitable distribution. (14)

Brands play an important role in determining marketing tricks; brands are also factors that can influence consumers' purchasing decisions by forming brand perception (14). Brands in foreign languages (foreign branding) are difficult to remember and pronounce, but brands in foreign languages in Indonesia have been popular for the past few years, despite the fact that the brand uses a foreign language, but the product is actually from Indonesia, and many consumers are duped into thinking that the product is from abroad.

There are several strategies that can be used to determine the identity of a product. The most common strategy employed by economic actors is the use of foreign languages for product identification. The following strategy is to use a technique known as a heavy point or something interesting in our product identity. This feature is what makes everyone who sees our product feel interested and easy to remember.

The advancement of communication technology has resulted in a decrease in the use of Indonesian in the community. Aside from the decreased public interest in using Indonesian, there are other factors that contribute to the language's downfall. The context of vocabulary in Indonesian is considered less important and does not vary as much as in foreign languages, so the delivery of objectives is not fully conveyed. This issue also has an impact on economic actors who want to produce goods. The use of Indonesian as a product's identity is considered ineffective in the public marketing process, and results in a product that is not as good or cool as one that uses a foreign language.

Furthermore, many economic actors who use foreign languages as product identities have a variety of methods and strategies in place to ensure that their products are not less competitive with other products. As a result, the researcher is interested in investigating this issue in order to determine how much influence a foreign language has on the identity value of a product. 
The researcher employs constructivism theory to investigate this issue. This theory emphasizes the fact that everything in the world is based on the concept of human thought. A society is built on the concept of human thought and the ability to generate new ideas that are accepted as true by society, rather than being held back by any one person or group of people, but must be open to change at every stage in human development.

Based on the context of the problem raised, several questions were asked, namely: How does a foreign language in the identity of a product affect the buyer's decision process?; What is the solution to re-expand the use of Indonesian for the identity of a product?

\section{METHOD}

This research uses literature review and interview. Literature review is a method that reviews all types of articles relevant to the studied case; by doing so, it will provide a foundation used to discuss and to develop results (39). While an interview is used to gather data from the public to further enhance the secondary data taken from various literature. We can build a solid foundation that is strengthened by primary data to discuss the answer.

The approach of this study is a qualitative method. A qualitative method is used to observe the studied object and it places the writer as a research instrument (35). To collect data, we use questionnaires (google forms) to get primary data and document research to get secondary data.

The library resources used are from 15 journals published in 2021,8 journals in 2020, 16 journals in 2019, 1 journal in 2017, and 1 journal in 2015. In addition, the primary data is obtained from questionnaires distributed to students in Airlangga University and their colleagues from 18 November to 20 December 2021.

\section{RESULT}

Table 1.

\begin{tabular}{|c|r|c|c|}
\hline No & Question & Option & Percentage \\
\hline \multirow{3}{*}{ 1. } & Would you rather buy a Local named product or \\
foreign named product? & $\begin{array}{c}\text { Local named } \\
\text { Product }\end{array}$ & $25 \%$ \\
\cline { 3 - 4 } & & Both & $25 \%$ \\
\hline
\end{tabular}




\begin{tabular}{|c|c|c|c|}
\hline & & $\begin{array}{l}\text { Foreign named } \\
\quad \text { Product }\end{array}$ & $50 \%$ \\
\hline \multirow[t]{3}{*}{2.} & \multirow[t]{3}{*}{ Which product is more attractive to you? } & $\begin{array}{l}\text { Local Named } \\
\text { Product }\end{array}$ & $40 \%$ \\
\hline & & Both & $20 \%$ \\
\hline & & $\begin{array}{l}\text { Foreign Named } \\
\quad \text { Product }\end{array}$ & $40 \%$ \\
\hline \multirow[t]{2}{*}{3.} & \multirow{2}{*}{$\begin{array}{l}\text { Have you ever been taught that a foreign language is } \\
\text { better than Indonesian language? }\end{array}$} & Yes & $80 \%$ \\
\hline & & No & $20 \%$ \\
\hline
\end{tabular}

Table 2.

\begin{tabular}{|c|c|c|c|c|c|}
\hline No & Question & Jonathan & Adinda & Rio & Ferrel \\
\hline 1 & $\begin{array}{l}\text { If you went to a store } \\
\text { and saw two products } \\
\text { with the item you } \\
\text { wanted, would you buy } \\
\text { a product in a foreign } \\
\text { language or a product } \\
\text { in Indonesian? }\end{array}$ & $\begin{array}{l}\text { Honestly, I } \\
\text { prefer a product } \\
\text { with the foreign } \\
\text { language }\end{array}$ & $\begin{array}{c}\text { Product that use } \\
\text { Indonesian } \\
\text { language }\end{array}$ & $\begin{array}{c}\text { Product that use } \\
\text { Indonesian } \\
\text { language }\end{array}$ & $\begin{array}{l}\text { Product with the } \\
\text { foreign language }\end{array}$ \\
\hline 2 & $\begin{array}{l}\text { Which product that you } \\
\text { find it more attractive? }\end{array}$ & $\begin{array}{c}\text { Product with } \\
\text { foreign } \\
\text { language }\end{array}$ & $\begin{array}{l}\text { Product with } \\
\text { Indonesian } \\
\text { Language }\end{array}$ & $\begin{array}{c}\text { Product with } \\
\text { Indonesian } \\
\text { Language }\end{array}$ & $\begin{array}{l}\text { Product with the } \\
\text { foreign language }\end{array}$ \\
\hline 3 & $\begin{array}{l}\text { If you choose a foreign } \\
\text { language product or If } \\
\text { you choose Indonesian } \\
\text { language products, why } \\
\text { is that? }\end{array}$ & $\begin{array}{l}\text { I choose foreign } \\
\text { language } \\
\text { product because } \\
\text { I once thought } \\
\text { that when a } \\
\text { product in a } \\
\text { foreign } \\
\text { language arrived } \\
\text { in Indonesia, it }\end{array}$ & $\begin{array}{l}\text { Indonesian- } \\
\text { language products } \\
\text { look more local } \\
\text { and maybe the } \\
\text { product has been } \\
\text { adapted to the } \\
\text { tastes or habits of } \\
\text { Indonesians. } \\
\text { These products }\end{array}$ & $\begin{array}{c}\text { When there is a } \\
\text { name, there is a } \\
\text { quality. }\end{array}$ & $\begin{array}{l}\text { Because if a } \\
\text { foreign product is } \\
\text { in a local store, it } \\
\text { means that the } \\
\text { product is } \\
\text { successful in the } \\
\text { international area }\end{array}$ \\
\hline
\end{tabular}




\begin{tabular}{|c|c|c|c|}
\hline & & $\begin{array}{l}\text { meant that the } \\
\text { product was } \\
\text { already on the } \\
\text { international } \\
\text { scene }\end{array}$ & $\begin{array}{l}\text { are also more } \\
\text { likely to be halal } \\
\text { because they have } \\
\text { gone through } \\
\text { several } \\
\text { procedures until } \\
\text { the product uses } \\
\text { Indonesian }\end{array}$ \\
\hline
\end{tabular}

Based on the data that we got from our surveys, the majority of the respondents that we asked choose product with foreign language rather than product with Indonesia language because most of them believe that if a foreign product is in a local store, it means that the product is successful in the international area. Some of the respondents also find that product with foreign language are more attractive than the product with Indonesian language because they think that it will give a new experience to them.

\section{DISSCUSSION}

\section{Foreign Language Concept}

Language is a tool for communicating verbal messages that contains meaning in every component and is used by individuals or social groups to meet similar needs.. While a foreign language, it isn't always the skilled or native language of a region or country; it is frequently used as language second or backup language at times positive and no longer used in everyday existence in a wide range of instances (22).

English is a global language that is widely used as the second language of a country by people from all over the world. English's position can be defined as a language with a strategic function, incorrectly one of the most frequently used languages for educational or expert needs, an era, and cross-border change (22).

\section{The Concept of Brand Identity}

A brand identity is a term that describes a consumer promise (33). To be effective, brand identity must connect through consumers. Identity brand is also something that distinguishes itself from other company brands and describes a future activity to be carried 
out by a company's organization. Brand image is a collection of a person's beliefs, ideas, and impressions about a brand; thus, it heavily influences customer attitudes and actions. According to Kotler and Keller, brand image is one of the most important pieces of evidence that brands have when it comes to attracting and keeping customers (22).

Every business company must have a brand. Improving a brand's reputation is very complicated and time-consuming task. When it comes to improving a brand, there are several strategies to consider, including the following:
a) Items must be memorable and unique.
b) It must be consistently improved.
c) Brands cannot be the same as those of other companies.
d) Interaction
e) Direct communication.

\section{Brand Association}

Brand equity includes the concept of brand association. Aaker (23) defines brand association as "anything that is directly or indirectly related to the customer's memory of a brand." The more consumers experience in consuming a brand or the more frequent appearances of the brand, the more impressions associated with the brand (27). Aaker in Marliani (2018) provides another definition: "Another strategic option is to associate one's brand with a country or region, which will increase its credibility." This definition implies that one of the strategic options is to associate a brand with a country or region in order to increase the brand's credibility (27).

According to Kotler and Keller (23) measuring brand image (brand image) can be done based on aspects of a brand.

a) Brand Association Strength

The more deeply an individual considers product information and connects it to existing brand knowledge, the stronger the brand association that is generated.

b) Preference for brand association

This results in the brand's ability to be easily remembered by consumers. Favourable brand associations are desirable consumer associations, such as a form of 
convenience, a dependable product, the message the product can convey, or a supportive marketing communications program.

c) Distinctive features of brand association

To provide a reason for consumers to buy it, the brand must have a sustainable advantage or a unique selling proposition.

\section{Foreign Language Branding}

A foreign brand is a branding strategy that involves giving a brand name with spelling or pronunciation in the language of certain foreigners, with the main goal of influencing the dimensions of brand image as well as consumer perceptions of quality and attitudes toward the product. Foreign language brands appeal consumer interest, and in general, the language used is from developed countries, with all of its benefits, resulting in a higher perception of product quality. Products with foreign branding are thought to be of higher quality when compared to other brands that provide little information.

A company's brand has become an important part of recognizing the product and differentiating it from other products. Because of the brand name, consumers have an easier time recognizing the product. According to Keller (23), brands help consumers identify the origin of a product. As a result, a local brand spelling certain foreign languages can present a signal that the product is from a specific country. Local producers frequently use this method to brand their products with spelling or writing in a foreign language. This phenomenon provides marketers with new insights in selecting brand products so that they can be associated with well-known country-made products that give consumers a positive perception.

According to Kapferer (23) there are points of reference to have a foreign language branding;

a. Due to the varying language and culture of different countries, a brand's meaning can vary. This, it is important that a company investigates its brand's potential negative or positive impact on consumers.

b. A brand should also be easy to remember and can be commonly recognized by the public. Language used for the brand should be chosen from countries that have a good 
reputation. The purpose of choosing the name is to convey the proper meaning for the type of product the brand is used for.

The correlation between foreign languages branding identity with constructivism is many business people believe that the use of a foreign language for their product identity will have a more attractive appeal compared to the use of Indonesian. The constructivist argument that the presence of a foreign language makes a product more recognizable reinforces this belief. For example, in the surrounding neighbourhood where there are businesses whose brand names use English language. Thus, if a new business appears next, it is almost certain that it will replicate what the previous business did.

\section{CONCLUSION}

Taking care of the product's identity is indeed important. The reasons why a company should maintain it are because it plays an important role for people's interest and to be able to compete with others. In this essay, researchers put brands in foreign languages as the main focus of a product and use constructivism as the point of view. Brands in foreign languages, despite their complexity and some people might find it difficult to pronounce, brands using foreign languages have been popular for a few years. This method surprisingly effective with evidence many economic actors using it and being popular among consumers

Researchers linked constructivism with the brand of a product, where the theory emphasizes all facts about the world based on the concept of human thought. It includes the concept of foreign language means that English is a global and commonly used language over the world, the concept of brand identity which important to connect products through consumers and to distinguish itself from others, brand association where more consumers experiencing in one brand make the brand discussed more frequently, and the last one about foreign language branding, a strategy of marketing using foreign language with the main goal of influencing of one brand image as well as consumers perceptions of quality toward it. It cannot be denied that foreign language attracts consumers' interest toward one product. That is why a brand becomes an important role of company for their product.

In conclusion, products' brands play a big role for consumers to recognize them. Maintaining a brand of one product is important if a company wants their product to be able 
to compete with others. It relates to those theories above: the concept of foreign language, the concept of brand identity, brand association, and foreign language branding. Those concepts tell reasons why using foreign language as branding is relevant and it is one of strategies of making products popular, attractive, and relevant.

\section{REFERENCES}

1. Amelfdi FJ, Ardyan E. Pengaruh brand awareness, Brand Image, Dan Kualitas Produk Terhadap Keputusan pembelian. PERFORMA. 2021;5(6):473-83.

2. Arafat Y. SISTEM PENDAFTARAN MEREK SEBAGAI UPAYA MENANGGULANGI PERSAMAAN MEREK YANG DAPAT MENGAKIBATKAN TIMBULNYA SENGKETA. Dinamika: Jurnal Ilmiah Ilmu Hukum. 2019;

3. Aruan L, Yohana C, Yusuf M. Peran Merek dalam Bahasa Asing dan Citra Merek terhadap Keputusan Pembelian. Jurnal Bisnis, Manajemen, Dan Keuangan. 2021;02(02).

4. Budiani, Ni Ketut, Sudiartini, Ni Wayan Ari, Astari, A.A Elik, Usadha, I Dewa Nyoman. Pengaruh Kualitas Produk Dan Brand Image Handphone Samsung Terhadap Purchase Intention Konsumen Pada Galeri Teknologi Di Badung. Jurnal Ilmiah Satyagraha. Universitas Mahendradatta; 2020; 2(2):17-45, ISSN 2723-5556.

5. Dimas Tutik A, Fitriani N, Inderasari E. Variasi Dan Fungsi ragam bahasa Pada iklan dan slogan situs Belanja Online Shopee. Imajeri: Jurnal Pendidikan Bahasa dan Sastra Indonesia. 2020;2(2):137-48.

6. Fajritami KN, Utomo HJ. Keputusan Pembelian Ditinjau Kualitas produk, label Halal Dan Brand Image. Paradigma: Jurnal Masalah Sosial, Politik, dan Kebijakan. 2021;25(2):564.

7. Fauzia AFZN, Sosianika A. Analisis Pengaruh Brand Image, Perceived Quality, dan Country of Origin Terhadap Minat Beli Produk Skincare Luar Negeri. Prosiding 12th Industrial Research Workshop and National Seminar (IRWNS). 2021Sep1;12.

8. Ida, Farida -. Analisis Pengaruh Brand Equity Terhadap Keputusan Pembelian Produk Oleh Oleh Khas Daerah Para Selebriti di Kota Makassar. JURNAL MANAJEMEN BISNIS. Universitas Muslim Indonesia; 2019; 6(1):32-40, ISSN 2621-1971.

9. Idzni SN, Saidani B, Fidhyallah NF. Pengaruh Brand Image dan Service Quality terhadap Customer Satisfaction Pengguna Wifi Rumah X. Jurnal Bisnis, Manajemen, Dan Keuangan. 2021;02(03).

10. Khasanah I, Laksmita D, Tilman RDC, Rizki R. Fenomena Penggunaan Bahasa Asing dalam Penamaan Bisnis Kuliner di Kawasan Soekarno Hatta Kota Malang. Jurnal Lingkar Widyaiswara. 2015;02(01):01-11.

11. Kurniasih N. Penggunaan Bahasa asing Dan Daerah Pada Papan Namausaha Dan Iklan (Studi Kasus di Banjarbaru Dan Martapura). UNDAS: Jurnal Hasil Penelitian Bahasa dan Sastra. 2019;14(1):92.

12. Kusuma AHP, Sudirman A, Purnomo A, Aisyah S, Sahir SH, Rumondang A, et al. Brand Management: Esensi, Posisi dan Strategi. Yayasan Kita Menulis; 2020.

13. Latukolan JJ, Marta RF, Engliana E. When words matter: Language choices and brand building on two global coffee shop retail brands in Indonesia. Budapest International Research and Critics Institute (BIRCI-Journal): Humanities and Social Sciences. 2021;4(2):2899-906. 
14. Masgumelar NK, Mustafa PS. Teori Belajar Konstruktivisme dan Implikasinya dalam Pendidikan dan Pembelajaran. GHAITSA : Islamic Education Journa. 2021;02(01).

15. Mubarok MAR, Rohaedi DRW. VARIASI BAHASA SLOGAN DALAM IKLAN SITUS BELANJA DARING TOKOPEDIA : KAJIAN SOSIOLINGUISTIK. 2021Jul9;

16. Munadzofzofah O. Pentingnya Bahasa Inggris, China, dan Jepang sebagai Bahasa Komunikasi Bisnis di Era Globalisasi. Jurnal Ilmiah Ilmu Administrasi dan Sekretari. 2017;01(02):58-73.

17. Nandaika, M Ega, Respati, Ni Nyoman Rsi. PERAN BRAND IMAGE DALAM MEMEDIASI PENGARUH GREEN MARKETING TERHADAP KEPUTUSAN PEMBELIAN (Studi pada produk fashion merek Uniqlo di Denpasar). E-Jurnal Manajemen Universitas Udayana. Universitas Udayana; 2021; 10(6):539, ISSN 23028912.

18. Ni Made, R. P. ANALISIS STRATEGI PEMASARAN DALAM MENINGKATKAN VOLUME PENJUALAN PRODUK BRAND GARUDA DI PT. SINAR NIAGA SEJAHTERA WILAYAH BALI NUSRA

19. Nurmala, D, Afningsih, N. PENGGUNAAN GAYA BAHASA CLICHÉ DALAM MENCIPTAKAN IKLAN MENARIK DALAM PEMASARAN PRODUK. ... SEMINAR NASIONAL HASIL .... e-prosiding.umnaw.ac.id; 2021

20. Poluan, Nadia Amelia. Pengaruh Rebranding Linkaja terhadap Peningkatan Brand Image Produk dan Loyalitas Pelanggan Grapari Graha Merah Putih. JURNAL SIMBOLIKA: Research and Learning in Communication Study. Universitas Medan Area; 2021; 7(1):27-34, ISSN 2442-9996.

21. Pradopo, LR. PENGARUH PEMBERIAN MEREK BERBAHASA ASING DAN CITRA MEREK CFC TERHADAP PENJUALAN PT PIONEERINDO GOURMET INTERNASIONAL TBK. Journal of Information System, Applied .... journal.stmikjayakarta.ac.id; 2019

22. Pramezwary, Amelda, Juliana, Juliana, Eagan, Billy, Putri, Feidora Jovanca, Setiadi, Steven. PENGARUH IDENTITAS BRAND DAN STRATEGI PENJUALAN BURGER KING TERHADAP KEPUTUSAN PEMBELIAN KONSUMEN. Cakrawala - Jurnal Humaniora. Universitas Bina Sarana Informatika; 2021; 21(1):1018, ISSN 2579-3314.

23. Pratami, R. Analisis Wacana Kritis Pada Penggunaan Bahasa Asing Dalam Iklan Televisi "Floridina". MEDIALOG: Jurnal Ilmu Komunikasi. jurnal-umbuton.ac.id; 2020.

24. Prawinata, Dikhi Hasdin. PENGARUH KUALITAS PRODUK DAN BRAND IMAGE TERHADAP KEPUASAN DAN LOYALITAS PELANGGAN PADA PT. COMINDO MITRA SULAWESI TELKOMSEL AUTORHIZED PARTNER. Bongaya Journal for Research in Management (BJRM). STIEM Bongaya; 2020; 3(2):14-20, ISSN 2615-8876.

25. Prayoga RA, Khatimah H. Pola pikir Penggunaan Bahasa inggris pada masyarakat perkotaan di jabodetabek. Simulacra: Jurnal Sosiologi. 2019;2(1).

26. Pujiastuti, Eny Endah, Sadeli, Sadeli, N, Luthfia Yumna. PENGARUH SOURCE CREDIBILITY, REVIEW QUALITY DAN REVIEW QUANTITY TERHADAP BRAND IMAGE DAN PURCHASE INTENTION (Studi Tentang Produk Wardah Pada Siswi Jurusan Kecantikan di SMK Negeri 6 Yogyakarta). Jurnal Ilmiah Administrasi Bisnis dan Inovasi. Dr. Soetomo University; 2020; 3(2):172-190, ISSN 2597-4092. 
27. Putra RP, Irwansyah I. Programmatic: Strategi Efektif Pemasangan iklan di era digital. Jurnal Studi Komunikasi (Indonesian Journal of Communications Studies). 2021;5(3):812-38.

28. Putri, Niken Anggoro, AY, Burhanudin, Sarsono, Sarsono. CITRA MEREK, KEPERCAYAAN MEREK, DAN KUALITAS PRODUK TERHADAP KEPUTUSAN PEMBELIAN HAND SANITIZER DETTOL PADA MASA PANDEMI COVID-19 DI LUWES GENTAN (Brand Image, Brand Trust, And Product Quality To Purchase Decision For Dettol Hand Sanitizer During-19 Pande. JURNAL EKBIS. Universitas Islam Lamongan; 2021; 22(1):69, ISSN 2621-4210.

29. Rahayu RS. STUDI LITERATUR: PERANAN BAHASA INGGRIS UNTUK TUJUAN BISNIS DAN PEMASARAN. Jurnal Pemasaran Kompetitif. 2018Jul;01(04).

30. Sanjiwani NM, Suasana IG. Peran brand image Dalam Memediasi pengaruh Kualitas Produk Terhadap Keputusan pembelian. E-Jurnal Manajemen Universitas Udayana. 2019;8(11):6721.

31. Santoso R, Erstiawan MS, Kusworo AY. Inovasi produk, Kreatifitas Iklan Dan Brand Trust Mendorong Keputusan Pembelian. JURNAL NUSANTARA APLIKASI MANAJEMEN BISNIS. 2020;5(2):133-45.

32. Setiadinanti, F, Nurhayati, IK. Pengaruh Merek Berbahasa Asing Terhadap Citra Merek Puyo Silky Dessert di Kota Bandung. JIM UPB (Jurnal Ilmiah .... ejournal.upbatam.ac.id; 2019;

33. Steven, Steven, Sari, Angelina Fitria Rina Sari Fitria Rina. PENGARUH PROMOSI DAN BRAND AWARENESS TERHADAP KEPUTUSAN PEMBELIAN PRODUK AQUA. Jurnal Ekonomi Integra. Jurnal Ekonomi Integra, STIE Indonesia Pontianak; 2019; 9(1):53, ISSN 2581-0340.

34. Suartama, I Ketut Catur Hery, Setiawan, Putu Yudi. PERAN BRAND IMAGE MEMEDIASI PENGARUH KUALITAS PRODUK TERHADAP NIAT BELI ULANG (Studi pada Smartphone Samsung di Kota Denpasar). E-Jurnal Manajemen Universitas Udayana. Universitas Udayana; 2019; 8(4):2555, ISSN 2302-8912.

35. Sugiyono. Metode Penelitian kuantitatif, kualitatif dan R \& D. 1st ed. Bandung, Jawa Barat: Alfabeta; 2014.

36. Tjokrosaputro, Maria Yoana Dan Miharni. Pengaruh Brand Experience, Brand Trust, Customer Satisfaction Terhadap Brand Loyalty Produk Cimory. Jurnal Manajemen Bisnis dan Kewirausahaan. Universitas Tarumanagara; 2019; 2(5), ISSN 2598-0289.

37. Trihudiyatmanto, M .. MEMBANGUN LOYALITAS PELANGGAN MELALUI KEPUASAN YANG DIPENGARUHI OLEH KUALITAS PRODUK, BRAND IMAGE DAN EXPERIENTIAL MARKETING. EKOBIS : Jurnal Ilmu Manajemen dan Akuntansi. Universitas Boyolali; 2021; 9(1):61-73, ISSN 2622-1756.

38. Tur AP. Iconic English business name as a branding tool in the rural areas of Yogyakarta Special Region. LITERA. 2019;18(1):136-49.

39. Watson R, Webster J. Analysing the past to prepare for the future: Writing a literature review a roadmap for release 2.0. Journal of Decision Systems. 2020;29(3):129-147.

40. Yuniarto, Haris, Nursal, M Fadhli, Panday, Rorim. PENGARUH BRAND IMAGE DAN JALUR DISTRIBUSI TERHADAP KEPUTUSAN PEMBELIAN FASHION BRANDED MATAHARI (STUDI KASUS PADA CUSTOMER BASE ONLINE SHOP PRODUK MATAHARI HARGA GUDANG). Jurnal Ilmiah Manajemen Ubhara. Universitas Bhayangkara Jakarta Raya; 2019; 1(2), ISSN 2684-7000. 